\title{
Assessment and Analysis of Urban Sprawl and Squatter Settlements in Calabar Metropolis
}

\author{
E. A. Agbor
}

\section{ABSTRACT}

Housing has since the dawn of urbanization been a major concern of individuals, groups and governments. The rapid population growth and uncontrolled urbanization are among the causes of the twin concepts of urban sprawl and squatter settlements in most urban centres including Calabar. Urban sprawl is seen as the spreading of cities towards the periphery to accommodate their growing population. Squatter settlements are described as residential areas developed without legal claim to the land or permission from the government, lacking infrastructural facilities such as water, electricity, waste disposal facilities, toilet and social services. They constitute substandard housing which are considered dangerous to health of individuals and a shame to human dignity. The aim of the study is to assess the rate of urban sprawl and squatter development in Calabar metropolis. The specific objective is to assess the socio-economic life of squatter settlers and to determine the causes and consequences of urban sprawl and squatter settlements in Calabar metropolis. Three squatter communities were identified to include Bakoko, Nyagasang and Atimbo. Each community represented a stratum from where 40 respondents were selected. A total of 120 copies of questionnaire were administered to respondents through systematic random sampling technique. Oral interview and direct observation techniques were employed. Secondary data were also obtained. The study reveals the causes of urban sprawl and squatter settlements and their effects. It highlighted the socio-economic characteristics of the three squatter settlements and made recommendations as a means to improve the socio-economic life and environmental quality of the inhabitants.

Keywords: Crime Rate, Insecurity, Housing Units, Squatter Settlements, Urban Sprawl

\author{
Published Online: December 22, \\ 2021 \\ ISSN: $2736-660 \mathrm{X}$ \\ DOI:
}

10.24018/ejdevelop.20211.4.56

\section{E. A. Agbor}

Department of Urban and Regional Planning, Cross River University of Technology, Calabar, Nigeria.

(e-mail: ajomagbor@gmail.com)

\section{INTRODUCTION}

Nigeria is among the fastest growing developing nations in the world with unprecedented rapid population growth and urbanization. Ufuoma (2001) observed that Nigeria has up to 5050 towns with each having population threshold of 20,000 or more located within 774 local government area. Ogunnowo (2002) also observed that as urban settlements continue to expand in size and number, the proportion of population also increases. Henderson (2002) noted that rapid urbanization in many developing nations have for over four decades been accompanied by high levels of population concentrations in large cities.

The United National Commission on Housing Settlement (UNCHS 2000) and the United Nation Development Programme (UNDP 2001) revealed in their studies that the population of Nigerians living in urban centres increase from less than $15 \%$ in 1950 to $23.47 \%$ and $43 \%$ in 1975,1980 and 1999 respectively. Odumosu (2004) also noted that there are 18 urban centres in Nigeria with a population of over 500, 000 people, 78, with over 100,000 people and 5000 with over 20,000 people. According to United Nation report (2002), $40 \%$ of the people in the developing countries now live in urban centres and it is expected to rise to $56 \%$ by 2030 .

This unprecedented rapid population growth through rural-urban migration and natural increase and uncontrolled urbanization usually lead to the concepts of urban sprawl and squatter settlements. It is worthy to note that while the population of Calabar metropolis is increasing at an alarming rate, there is no complementary increase in the development of new dwelling units. Where such dwelling units are available, the rent is always exorbitant making it difficult for the low income population to acquire a decent house. This implies that there is always an increase in the demand for alternative low-cost housing accommodation which leads to urban sprawl to the city's periphery.

The vacancy rate in squatter settlements is very low. This is because the new buildings are occupied by tenants who are willing to pay to the landlords considering their income. It is not surprising therefore that 
the squatter housing units are in high demand. Thorns (1976); Obongha and Ukam, (2020) observed that the proportion of squatters to city population is increasing as the urban population increases in Africa and other less developed countries of the world. This study is an attempt to check the growth pattern of Calabar urban periphery from becoming potential slums.

\section{Aim AND OBJECTIVES}

The aim of this study is to assess the rate of urban sprawl and squatter development in Calabar metropolis.

The specific objective is to assess the socio-economic life of squatter settlers and to determine the causes and consequences of urban sprawl and squatter settlements in Calabar metropolis.

\section{THE STUDY AREA}

The ancient city of Calabar otherwise known as "Canaan city" or the "City of Paradise" has been the central point of activities and the administrative Headquarters of the Cross River State government of Nigeria. Calabar was the first national administrative capital of Nigeria from 1882 - 1906 during the early British rule. It is located between latitude 4056' and 5004' North of the equator and longitude 8018' and 8024' East of the Greenwich Meridian. The city lies on the peninsular between the Calabar River on the nearest buildable land to the sea as shown on Fig 3. Currently referred to as the Tourism Destination'" of Nigeria, Calabar remains one of the oldest city and port in the West African sub-region and a slave trade depot along the Bight of Biafra (Bonny).

Calabar is a dynamic urban centre with a rural-urban migrant population. The population of Calabar Metropolis had been estimated to be 82,100 in 1975, 159,599 people in 1978, 140,200 in 1985, 217,800 in 1995, 320,862 in 1991, and 375,196 people in 2006 census. The indigenes are the Efiks, the Quas and the Efuts who engaged themselves in commercial, industrial, educational and small scale farming. Climatically the city of Calabar falls within the rain forest belt with tropical vegetation.

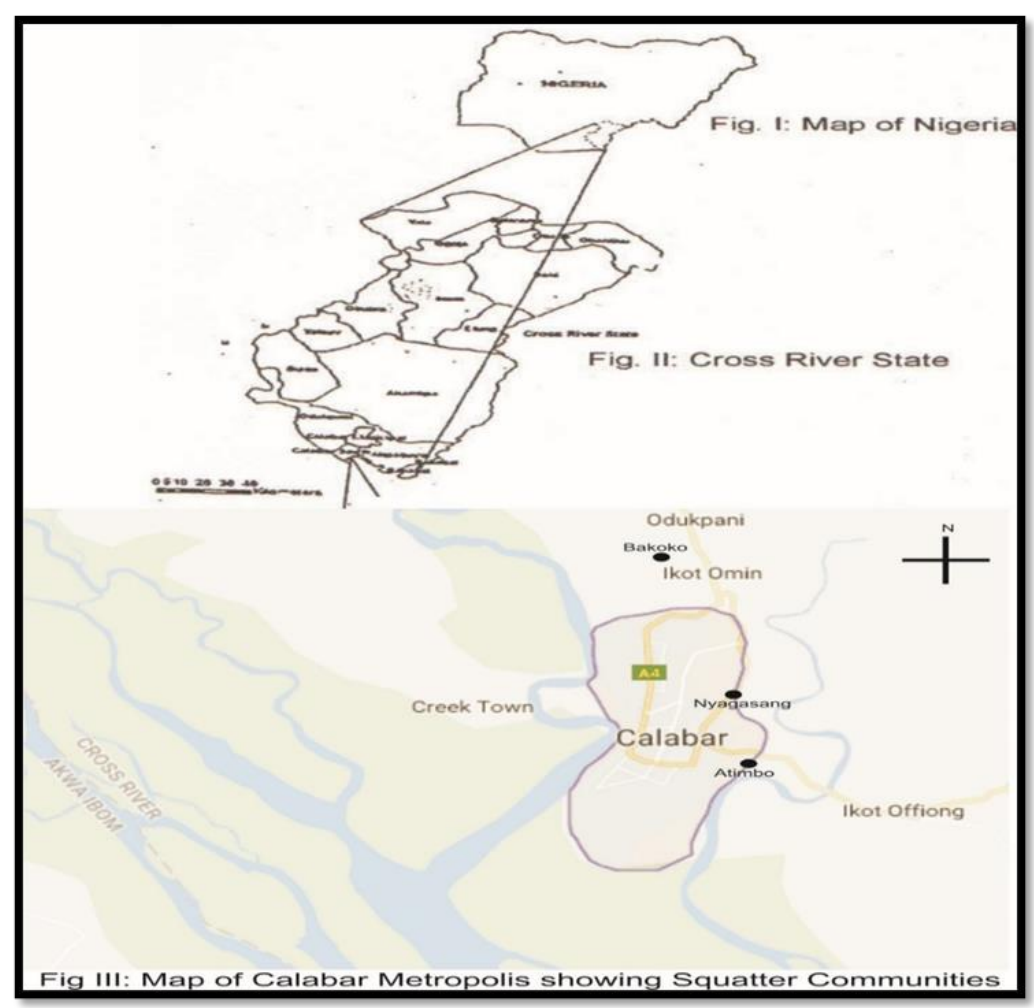

Fig. 3. Map of Calabar Metropolis showing squatter communities.

\section{THEORETICAL UNDERPINNING}

Urban sprawl is the process of spreading out of an urban area and its suburbs over rural land at the periphery of a city. It is perceived as a negative urban form with consequences which include haphazard and un-aesthetic development, poor access to services for people with limited mobility especially the young and the elderly, congestion and increase in fuel consumption due to low densities, dependence on the use of automobile, loss of agricultural land and open space, poor health and environmental problems. 
The concept of urban sprawl has received extensive attention in the literature since the 1980's but despite the wealth of information the nature of sprawl and its impact on city form and urban function remains unilluminated. Abimbola (2008) also observed that urban sprawl has become a pejorative term without any serious examination of its qualities or benefits and without any critical analysis of its troubled alternative urban congestion while the formation of the world's cities has always been determined by the means of available transport. He went further to note that at first people worked in cities but lived in sprawling suburb making edge cities the dominant urban form. Michael (2005) opined that urban sprawl is also known as suburb sprawl and a multifaceted concept which is the spreading outward of a city and its suburb to it outskirts to low density and auto-dependent and development on rural land with high segregation of uses. He further observed that the aim of creating sustainable and compact cities is inhibited by urban sprawl due to uncontrolled development. Smith (2009) defined urban sprawl as uncontrollable spread of urban development over rural landscapes, calling on city planners to adopt zoning in supervising growth and the spread of population. Brueckner (2000) expressed strong sentiment against urban sprawl phenomenon which developed over the last five years in the United State. He further observed that many local governments and states have adopted and design policies to address sprawl. Bruecker observed further that excessive urban expansion gives rise to long commuters which generate traffic congestion and contributing to air pollution.

Sule (2006) observed that the growing city population without a corresponding economic growth is responsible for rural-urban migration in developing countries which also result to urban sprawl. Neha (2004) identified causes of urban sprawl to include population growth, increasing per capita income, subsidization of infrastructure, investment and physical constraints on development. He further observed that sprawl is a matter of preference and that the incomes of the people in developed countries are higher than incomes in the developing countries which are responsible for urban sprawl. Mieszkowski and Mills (1993) identified three causes of urban sprawl to include population growth, rising household income and transportation improvements. They observed further that as the nation's population expand, cities must also expand to accommodate more people. The duo opined further that rising income affect urban growth because when incomes of the residents improve over time, they will demand more living space.

Urban sprawl promotes inefficient use of land and energy, encroachment on green space, loss of agricultural land and ground water. The impacts of urban sprawl include population growth, reliance on fossil fuel increase in cases of obesity, less of land and social capital, and water quality. Fiore (2007) observed that urban sprawl imposes negative impact on the environment which include loss of green space, farmlands, poor water quality and decrease in ground water, poor air quality due to increase use of private cars, loss of wetlands, wildlife, and the creation of heat island.

\section{SQuatter SettLement}

Squatter settlement is an area usually identified as unplanned with chaotic development. It comprises of non-compliance to building regulation such as violation of building lines and ventilation, inadequate or completely lack of facilities and services, overcrowding of structures and people, building along utility lines etc. This negligence most often lead to environmental decay capable of posing danger to human health, traffic injury, death and undermines civic pride.

Turner (1968) view squatter settlement as any residential area which has been developed without legal claim to the land and or permission from the concerned authorities to build. That infrastructure and services such as water, electricity, waste disposal, toilets and social services are unavailable or inadequate as a result of their illegal or semi-legal status. Squatters are either rural-urban or urban-urban. Substandard housing has been a major problem in Nigerian urban centres. Houses in squatter settlements in developing nations are dangerous to the health of individuals and a shame to human dignity. Osuide (2005) observed that a good house enhances the wellbeing and aspiration of its occupants. He further noted that having a safe place to live in is one of the fundamental elements of human dignity, physical and mental health, and overall quality of life which enhances human development. Saarinen (1966) in Agbor (2014) observed that the family and its home are the corner-stone of society, and man's physical and mental development depend largely upon the character of the environment in which he is natured as a child, where he spent his manhood and where he does his work. The United National Centre for Human Settlement (UNCHS-habitat 2000) observed that nearly half of the world's population now live in cities and that over one billion of the world's city residents live in inadequate and deficient housing. The study further revealed that the problem is more felt in Africa, Asia and Latin America. The study noted that nearly 80\% of the urban population live in slum and squatter settlements without water, electricity, sanitation, waste disposal etc.

The fact remains that many Nigerian cities have been over priced beyond the affordability of many urban citizens such that many poor new immigrants and other poor city residents find it cheaper to build shanty neighborhoods otherwise known as squatter settlements which are more or less slums. Agbor (2005) 
observed that squatter are taking over every vacant space in city centres of Lagos, Port-Harcourt, Kano, Kaduna, Ibadan, Onitsha, Aba etc. and putting up shacks of tin, wood and cardboard for shelter. Adding that each of these cities has nothing less than 50 percent of its total population as squatters. This squatter settlement scenario and urban sprawl in Calabar metropolis has call for this study.

TABLE I: DEMOGRAPHIC AND SOCIO-ECONOMIC CHARACTERISTICS OF RESIDENTS IN SQUATTER COMMUNITIES IN CALABAR METROPOLIS

\begin{tabular}{|c|c|c|c|c|c|}
\hline Communities & Frequenc & nts it & mmunities & \multirow{2}{*}{ 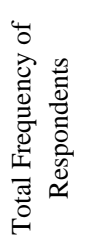 } & \multirow{2}{*}{ 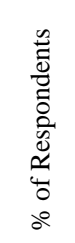 } \\
\hline Age or Respondents & 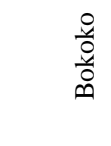 & 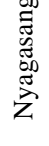 & $\frac{8}{E}$ & & \\
\hline $21-30$ & 12 & 8 & 7 & 27 & 22.50 \\
\hline $31-40$ & 14 & 10 & 13 & 37 & 30.83 \\
\hline $41-50$ & 10 & 13 & 15 & 38 & 31.67 \\
\hline 51 and above & 4 & 9 & 5 & 18 & 15.00 \\
\hline Total & 40 & 40 & 40 & 120 & 100.0 \\
\hline \multicolumn{6}{|l|}{ Gender } \\
\hline Male & 21 & 25 & 23 & 69 & 57.50 \\
\hline Female & 19 & 15 & 17 & 51 & 42.50 \\
\hline Total & 40 & 40 & 40 & 120 & 100.0 \\
\hline \multicolumn{6}{|l|}{ Monthly Income } \\
\hline $3000-4000$ & 10 & 15 & 12 & 37 & 30.83 \\
\hline $5000-6000$ & 13 & 12 & 10 & 35 & 29.17 \\
\hline $7000-8000$ & 9 & 8 & 7 & 24 & 20.0 \\
\hline 9000 and above & 8 & 5 & 11 & 24 & 20.0 \\
\hline Total & 40 & 40 & 40 & 120 & 100.0 \\
\hline \multicolumn{6}{|l|}{ Education } \\
\hline Primary & 12 & 9 & 11 & 32 & 26.67 \\
\hline Secondary & 7 & 16 & 8 & 31 & 25.83 \\
\hline Post-Secondary & 5 & 7 & 12 & 24 & 22.00 \\
\hline No Education & 16 & 8 & 9 & 33 & 27.50 \\
\hline Total & 40 & 40 & 40 & 120 & 100.0 \\
\hline \multicolumn{6}{|l|}{ Occupation } \\
\hline Farmer & 10 & 12 & 11 & 33 & 27.50 \\
\hline Civil Servant & 6 & 9 & 12 & 27 & 22.50 \\
\hline Trading & 11 & 8 & 9 & 28 & 23.33 \\
\hline Artisan & 8 & 7 & 5 & 20 & 16.67 \\
\hline Others & 5 & 4 & 3 & 12 & 10.00 \\
\hline Total & 40 & 40 & 40 & 120 & 100.0 \\
\hline \multicolumn{6}{|l|}{ Household Size } \\
\hline $0-2$ & 0 & 4 & 3 & 7 & 5.80 \\
\hline $3-4$ & 3 & 6 & 8 & 17 & 14.20 \\
\hline $5-6$ & 11 & 8 & 7 & 26 & 21.70 \\
\hline $7-8$ & 14 & 13 & 12 & 39 & 32.50 \\
\hline 9 and above & 12 & 9 & 10 & 31 & 25.80 \\
\hline Total & 40 & 40 & 40 & 120 & 100.0 \\
\hline
\end{tabular}


TABLE II: DISTRIBUTION OF HOUSING UNITS BY BUILDING MATERIALS

\begin{tabular}{|c|c|c|c|c|c|}
\hline \multicolumn{4}{|c|}{ Communities } & \multirow[b]{2}{*}{ 吾 } & \multirow[b]{2}{*}{ 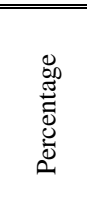 } \\
\hline 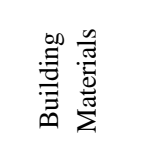 & 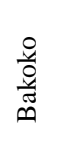 & 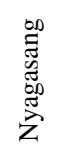 & 惫 & & \\
\hline Cement & 6 & 9 & 8 & 23 & 19.17 \\
\hline Mud Block & 8 & 10 & 10 & 28 & 23.33 \\
\hline Zink & 12 & 9 & 10 & 31 & 25.80 \\
\hline Wood & 10 & 9 & 10 & 29 & 24.20 \\
\hline Others & 4 & 3 & 2 & 9 & 7.50 \\
\hline Total & 40 & 40 & 40 & 120 & 100.00 \\
\hline
\end{tabular}

TABLE III: DISTRIBUTION OF HOUSING FACILITIES IN SQUATTER COMMUNITIES

\begin{tabular}{|c|c|c|c|c|c|}
\hline \multirow[b]{2}{*}{ Source of Water Supply } & \multicolumn{3}{|c|}{ "Frequency of Respondents in Squatter Communities } & \multirow[b]{2}{*}{ 离 } & \multirow[b]{2}{*}{ 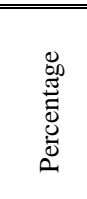 } \\
\hline & 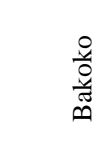 & 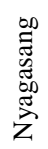 & 道 & & \\
\hline Pipe borne & 3 & 02 & 4 & 9 & 7.50 \\
\hline Borehole & 4 & 5 & 6 & 15 & 12.50 \\
\hline River/stream & 10 & 12 & 9 & 31 & 25.83 \\
\hline Local well & 14 & 13 & 16 & 43 & 35.83 \\
\hline Water vendor & 9 & 8 & 5 & 22 & 18.00 \\
\hline Total & 40 & 40 & 40 & 120 & 100.00 \\
\hline \multicolumn{6}{|l|}{ Electricity } \\
\hline PHCN/NEPA & 4 & 8 & 8 & 20 & 16.70 \\
\hline Generator & 11 & 10 & 10 & 31 & 25.80 \\
\hline Kerosine lamp & 13 & 11 & 12 & 36 & 30.00 \\
\hline Gas lamp & 5 & 7 & 5 & 17 & 14.20 \\
\hline Candle & 7 & 4 & 5 & 16 & 13.30 \\
\hline Total & 40 & 40 & 40 & 120 & 100.00 \\
\hline \multicolumn{6}{|l|}{ Toilet } \\
\hline $\begin{array}{c}\text { Water closet } \\
(\mathrm{W} / \mathrm{C})\end{array}$ & 5 & 10 & 11 & 26 & 21.70 \\
\hline Pit laterine & 13 & 15 & 14 & 42 & 35.00 \\
\hline Bush & 16 & 13 & 15 & 44 & 36.70 \\
\hline Others & 6 & 2 & 0 & 8 & 6.60 \\
\hline Total & 40 & 40 & 40 & 120 & 100.00 \\
\hline \multicolumn{6}{|l|}{ Kitchen } \\
\hline In-house & 6 & 11 & 10 & 27 & 22.50 \\
\hline Separated & 16 & 14 & 17 & 47 & 39.20 \\
\hline None & 18 & 15 & 13 & 46 & 38.30 \\
\hline Total & 40 & 40 & 40 & 120 & 100.00 \\
\hline \multicolumn{6}{|l|}{ Bathroom } \\
\hline In-house & 8 & 10 & 12 & 30 & 25.00 \\
\hline Separated & 18 & 17 & 16 & 51 & 42.50 \\
\hline None & 14 & 13 & 12 & 39 & 32.50 \\
\hline Total & 40 & 40 & 40 & 120 & 100.00 \\
\hline
\end{tabular}

\section{FINDINGS AND DISCUSSION}

The demographic and socio-economic characteristics of respondents presented in Table I shows that the residents between the ages of 31-50 years $(30.83 \%$ and $31.67 \%)$ respectively formed the majority in the squatter communities. The economic implication is that these residents are independent and economically active than those in the ages of $21-30$ and above 50 years. The economically active age is involving in small-scale farming and business enterprises at the city's periphery to sustain their families. Generally, $57.50 \%$ are male while $42.50 \%$ are female in the communities.

The data on Table I further reveal low monthly income for squatter settlers. Those who earned N3,000 N4,000 represent 30.83percent while those between N5,000 - N6,000 represent 29.17percent. Respondents who earn between N7,000 and N8,000 represent 20 percent and 20 percent for those who earned N9,000 and above. This is an indication of poverty. Neha (2004) observed that income in the developed countries are higher than incomes in the developing countries which is responsible for urban sprawl.

The table also reveal that 27.50 percent of respondents have no formal education, 26.67 percent have 
primary education, 25.83 percent have secondary while only 2.0 percent have post-secondary education. Table I also reveal that farmers represent 27.50 percent, 23.22 percent for trading activities, 22.50 percent civil servants, 16.67 percent artisans and others with 10percent. Lack of job opportunities in urban centres usually lead to sprawl to the city's periphery to be engage in farming, trading as indicated on the table above. There is observed increase in household size of 32.50 percent for 7-8 persons, followed by 25.80 percent for 9persons and above, 21.70 percent for 5 -6 persons, 14.20 percent for 3-4 persons and only 5.80 percent for 0-2 persons. This is evidence of housing shortage in large urban centres which causes congestion and overcrowding in substandard houses in squatter communities.

The findings in Table II reveal that 25.50 percent of the buildings in the squatter communities were built with zinc, 24.20 percent respondents used wood, 23.33 percent used mud blocks 19.17 percent used cement while others represent 7.50 percent. These are substandard houses which are dangerous to the health of individuals and shame to human dignity. According to Osuide (2004) a good house enhances the wellbeing and aspiration of its occupants.

Table III shows the distribution of housing facilities in the squatter communities in Calabar metropolis. The major source of water supply in these communities is local wells which accounts for 35.83 percent, followed by river/streams which account for 25.83 percent, water vendor 18.0 percent, borehole 12.50 percent and 7.50 percent for pipe-borne water. The major sources of electricity supply are the use of kerosene lamp which account for $30 \%$ and $25.80 \%$ for generator. The use of Power Holding Company (PHCN/NEPA) account for $16.70 \%$ while gas lamp and candle account for $14.20 \%$ and $13.30 \%$ respectively.

Data on Table III further reveal toilet facilities as follows, water closet (W/C) $21.70 \%$, pit toilet $35 \%$, bush $36.7 \%$ and other sources $6.6 \%$. Under kitchen facility $39.20 \%$ respondents have their toilet separated from their houses, $25.50 \%$ have toilet inside their houses while $38.30 \%$ respondents do not have toilets. Under bathroom $25 \%$ respondents have baths inside the house, $42.50 \%$ have bathroom separated from their houses and $32.50 \%$ do not have bathroom which implies taking their bath outside. The absence of housing facilities is unsafe and dangerous to human health. Having a safe house to live in is one of the fundamental elements of human dignity, physical and mental health, and overall quality of life which enhances human development.

\section{CAUSES OF URBAN SPRAWL AND SQUATTER SETTLEMENTS}

The following causes of urban sprawl and squatter settlements were revealed during oral interview with the respondents in the three squatter communities. Over population; shortage of accommodation and increasing rate of eviction; crime and insecurity in central cities; inadequate basic infrastructural facilities and services; the desire for better employment opportunities; increase in house rent; improve transport technology; low cost of travel; rapid urbanization and emergence of mega cities; rising household income; changing land policies; and the desire for farm lands.

\section{CONSEQUENCES OF SQUATTER SETTLEMENTS}

Unplanned growth and haphazard leapfrog development; loss of agricultural land and open space; dependence on automobile use; traffic congestion and increase fuel consumption; overcrowding of people and structures; increase travel distances; increase obesity; poor sanitation (poor waste disposal) high incidence of diseases; high crime rate (theft, rape, murder, assault, drug addiction and prostitution); rising illiteracy level; stress, fatigue and mental breakdown; poor building materials; ugliness and chaos; poor water quality; loss of wetlands, etc.

\section{RECOMMENDATION}

There is need for the provision of low cost housing at affordable cost for the poor immigrants in our urban centres who have come to seek for better living standards. Government and the private sector should create employment opportunities for the growing urban population. This will reduce crime and insecurity in central cities. There is also need for the provision of basic facilities like water, electricity, drainage, waste disposal etc. Other facilities and services like health care, markets, recreation, transport etc should be extended to the city periphery to enhance the wellbeing and improve the living condition of the inhabitants.

Government and financial institutions should make available loans and repair grants at low interest rates to home owners to build and carry out routine renovation of their properties.

Demolition option of squatter settlements by government officials should be discouraged, as it might increase housing need. Rather the settlements should be reorganized in a homogenous manner with the 
provision of basic infrastructural community facilities. For instance, the realignment of some buildings within the settlements is most appropriate. This will provide easy access, reduce the outbreak of fire incidence and epidemic. This approach will improve ventilation and enhance environmental quality of the area.

Government should embark on vigorous environmental education campaign to inform the inhabitants on the need to clean their environment for healthy living.

\section{CONCLUSION}

The housing situation in Nigeria has brought serious challenges which are not unsurmountable if innovative human settlement policies are adopted. Among them include the provision and maintenance of the existing housing stock and infrastructural facilities and services; making land accessible to the poor and the adoption of land policies that determines the rights and obligations of land owners and developers; cooperation among the actors involve i.e. the Federal, State, Local governments, and the private sectors; community participation in settlement policies, development and management; the introduction of employment and financial opportunities, rent reduction and security of tenure and public enlightenment campaign for the general public to improve their shelter and environment. The present scenario of urban sprawl and squatter settlement can be reversed through the adoption of the above innovative policies.

\section{ACKNOWLEDGMENT}

I sincerely appreciate all the Authors whose materials were consulted while conducting this research. I also want to appreciate the Officials of Calabar Municipal Council and Calabar South L. G. A., Cross River State GIA for their maximum support. My gratitude also goes to my dear wife, children and colleagues at work who also assisted when undergoing this research and I pray God Almighty to grant you all your heart desires.

\section{REFERENCES}

Abimbola, T. (2008). The Planning implication of urban sprawl in Akure. 44th ISOCARP Congress.

Agbor, E. A. (2014). Analysis of quality of housing environment in IKom Urban. Nigeria: Cross River State.

Bruecknar, J. K. (2000). Urban Sprawl: Diagnosis and Remedies. International Regional Science Review, $23(2), 160-171$.

Fiore, C. (2007). The environmental impact of urban sprawl. April 6.

Henderson, V. (2002). Urbanization in developing countries. The World Bank Research Observer. 17(1) (Spring).

Mieszkowski, P. \& Mills E.S. (1993). The Causes of metropolitan suburbanization. Journal of economic perspectives, $7,135-49$.

Neha, M. (2004). Urban Sprawl: A developing country approach. Journal of the World Student community for sustainable development.

Obongha, U. E. \& Ukam, L. E. (2020). The Impact of settlement pattern of some Nigerian cities on the spread Covid-19 Pandemic. European Journal of Environment and Earth Sciences, 1(4), 1-6.

Odumosu, T. (2004). The catalo-Reactant of Development: Urbanization through the Age: Inaugural Lecture. University of Lagos (LASU) Lagos Free Enterprise Publishers, Thursday 11th March.

Ofuoma, P. (2001) "Nigeria to host global campaign on urban Governance" The pubch, Monday, 16th April, p.23.

Ogunnowo, C. O. (1998). Urban waste management in Nigeria. Trend and issues. Journal of Arts and Social Sciences (JASS), 4(1), 88-96.

Osuide, S. O. \& Dimuna, K. O. (2005). Effects of population growth on urbanization and the environment in Nigeria. In proceedings of year 2000 National Seminar on Pop. Growth. Architecture and the Environment (pp. 27-33), Rasjel Publishers. Ekpoma.

Sule, R. O. (2006) Paradigm of Urbanization and Urban Planning, Nigeria based Switzerland.

Thorns, D. C. (1976). The quest for community - Social Aspects of Residential Growth. New York: John Wiley and Sons.

Turner, J. (1968) Uncontrolled Settlement: Problems and politics. International Social Development.

UNCHS (2000). The United Nation Centre on Housing Settlement.

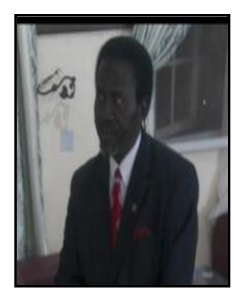

Tpl. Dr. E. A. Agbor is an Associate Professor of Urban and Regional Planning, Cross River University of Technology, Calabar, Nigeria. Former HOD of Urban and Regional Planning and currently, Dean of Faculty of Environmental Sciences in the same University. He is also Member of the Nigerian Institute of Town Planners and Registered with the Town Planners Registration Council of Nigeria as a Consultant Practicing the Profession of Urban and Regional Planning in Nigeria. He has numerous publications to his credit with more than 30 years' of research and University teaching experience. 